\title{
Heavy metal uptake by plant parts of willow species: A meta-analysis
}

\author{
Dávid Tőzsér, Tibor Magura, Edina Simon* \\ Department of Ecology, University of Debrecen, Egyetem sq. 1, H-4032 Debrecen, Hungary
}

\section{A R T I C L E IN F O}

\section{Article history:}

Received 3 November 2016

Received in revised form 13 March 2017

Accepted 15 March 2017

Available online $\mathrm{xxx}$

\section{Keywords:}

Meta-analysis

Phytoremediation

Salix

Contamination

Accumulation

\begin{abstract}
A B S T R A C T
Previous studies on phytoremediation reported contradictory or inconsistent results on the $\mathrm{Cd}, \mathrm{Pb}$, and $\mathrm{Zn}$ accumulation in and among plant parts of willow (Salix) species. We hypothesized that metals could accumulate in all plant organs in different concentrations and the metal accumulation in tissues would be increased with exposure time. Furthermore, we analysed the effect of soil $\mathrm{pH}$ on metal accumulation, and the correlation between metals. We evaluated published information on $\mathrm{Cd}, \mathrm{Pb}$, and $\mathrm{Zn}$ accumulation in root, stem, twig, and leaf of willow species using meta-analysis. Results showed that all parts of willow species accumulated significantly more $\mathrm{Cd}, \mathrm{Pb}$, and $\mathrm{Zn}$ in contaminated soils than in uncontaminated soils. However, the metal accumulation was significantly different among plant parts. We concluded that willow species were proven to be prosperous accumulators of $\mathrm{Cd}$ (twigs and leaves), $\mathrm{Pb}$ (roots and twigs) and $\mathrm{Zn}$ (twigs). We found that $\mathrm{Cd}$ accumulation rate in stems is higher in soils with lower $\mathrm{pH}$. Significant positive correlation was found between the accumulations of $\mathrm{Cd}$ and $\mathrm{Zn}$ in stems. Accumulation rates of $\mathrm{Cd}$ (both in leaves and twigs) and $\mathrm{Zn}$ (in twigs) were increased significantly with exposure time and the accumulation was successful for at least 3 years.
\end{abstract}

(C) 2016 Published by Elsevier Ltd.

\section{Introduction}

Global environmental problems are among the main challenges of the 21st century [1]. Frequent irresponsible and inadequate land use (e.g. managing former and current industrial and mining sites) or demands claimed by population growth (e.g. food supply, urbanization) cause soil pollution, which is one of the most urgent worldwide problems to eliminate [2-5].

Cleaning up contaminated sites with traditional remediation methods places a huge financial strain on stakeholders [6,7]. During the last few decades, researchers found that numerous plant species can accumulate high amount of metal(s) from growing media with low and moderate level of contamination, without suffering severe physiological damages [8-10]. Several studies demonstrated that phytoremediation is an efficient, low-cost, socially acceptable group of remediation processes, establishing long term (years to decades) vegetation cover [11-14]. There are different methods of application of plants in restoring contaminated areas, which depend on the properties of contaminants and the aims of remediation [15]. Besides the phytoextraction mechanism, phytostabilization, phytofiltration, phyto- and rizo-degradation, phytovolatization and phytohydraulics are also in application to extract, stabilize, filtrate, degrade, volatize and hydraulically control the extant contaminants or pollutants, respectively [16-18].

In the case of phytoextraction, accumulation rate and availability of metals are functions of various internal and external factors, in-

\footnotetext{
* Corresponding author.

Email address: edina.simon@gmail.com (E. Simon)
}

cluding growth stage, time of exposure, concentrations and forms of metals, interactions between metals, and soil properties [19-21]. Additionally, phytoextraction process can only be successful by sufficient plant density [22]. In the case of plant-heavy metal interaction, two main plant strategy groups can be distinguished: excluders and accumulators [23-25]. The members of excluders concentrate the metal(s) in their roots, while the accumulator plants transfer metal(s) to their aboveground tissues. Metal concentrations are relatively higher in tissues of accumulator plants than in the soil [26-28].

When considering species applicable for phytoextraction, the following features are highly relevant: remarkable metal-tolerance (accumulation potential), high biomass yield and fast growth [29-31]. Among metal-accumulator species, Salix (willow) is a widely studied genus [7,18,32]. Based on the results of earlier reports, 10 of the 450 known Salix species have been monitored in regard to phytoremediation $[33,34]$. Besides the common beneficial features of Salix species in application for phytoremediation, previous studies reported contradictory or inconsistent results on the rate of metal (in this case $\mathrm{Cd}$, $\mathrm{Pb}$, and $\mathrm{Zn}$ ) accumulation in and among plant parts $[6,35,36]$. Within an extensive pot experiment, Dos Santos Utmazian and Wenzel [31] studied the $\mathrm{Cd}$ and $\mathrm{Zn}$ accumulation potential on several European Salix clones. They concluded that metal concentrations were generally higher in leaves than in roots. At the end of a 3-month long exposure time study Rosselli et al. [37] measured higher Zn concentration in roots than in leaves. Studying Cd concentration in seven Salix clones, at the end of a 6-year experiment Tlustoš et al. [38] found the highest heavy metal concentration in leaves, followed by comparable concentrations in twigs and wood, while the $\mathrm{Cd}$ accumulation in roots was significantly lower. The highest $\mathrm{Zn}$ concentration was measured in leaves, while twigs, wood and root tissues accumulated $\mathrm{Zn}$ in sig- 
nificantly lower concentrations. They found that $\mathrm{Pb}$ was accumulated primarily in roots, followed by wood and twig tissues, while the translocation to leaves was negligible. Heavy metal accumulation of four Salix clones was studied by Ruttens et al. [39] who found that $\mathrm{Pb}$ concentration was higher in leaves than in stem tissues, in the case of three of the four clones.

The aim of our study was to analyse the available published data on $\mathrm{Cd}, \mathrm{Pb}$, and $\mathrm{Zn}$ accumulations among the selected plant parts (root, stem, twig, and leaf) of willow species growing in contaminated soils, using meta-analysis. In this paper, we studied the accumulations of $\mathrm{Cd}, \mathrm{Pb}$, and $\mathrm{Zn}$, because these metals are involved in phytoremediation studies the most frequently. Furthermore, sufficient amount of data were available for the meta-analysis only in the cases of $\mathrm{Cd}, \mathrm{Pb}$, and $\mathrm{Zn}$. We hypothesized that metals would be accumulated in all plant organs, but in different concentrations. In addition, we studied the effect of soil $\mathrm{pH}$ on metal accumulation. We studied whether acidic soil $\mathrm{pH}$ increased the mobility, availability and accumulation of metals in willows. Furthermore, correlations between the studied metals were also assessed; synergism was hypothesized between $\mathrm{Cd}$ and $\mathrm{Zn}$ accumulations. Moreover, we investigated if $\mathrm{Cd}, \mathrm{Pb}$, and $\mathrm{Zn}$ accumulation rates in tissues would be increased with exposure time.

\section{Experimental}

\subsection{Literature search and data selection}

We collected data by performing a literature search on Web of Science for the period 1975-2016, using the following search terms: TOPIC $=($ Salix $)$ AND TOPIC $=($ metal OR phytoremediation $)$. Additionally, we scanned the reference section of the papers found in this search for additional, undetected, relevant publications. To be included, a publication had to report metal $(\mathrm{Cd}, \mathrm{Pb}$, and $\mathrm{Zn})$ concentration ( \pm SD and sample size) in plant parts (root, stem, twig, leaf) of willow species growing in contaminated vs. uncontaminated (control) soils. Data on tissues referred to as stem + wood in the papers were classified as stem in the meta-analysis. Data were extracted from text, tables, and graphs. Studies in which any compounds (e.g. EDTA) had been applied to facilitate metal uptake were excluded from the analyses, in order to study the inherent phytoextraction capacity of willow species exclusively.

\subsection{Statistical analyses}

For each uncontaminated-to-contaminated comparison, the unbiased standardized mean difference (Hedges' $g$ ) as a common effect size was calculated between uncontaminated and contaminated group:

$$
g=J \frac{\overline{X_{U}}-\overline{X_{C}}}{S_{\text {within }}}
$$

$$
S_{\text {within }}=\sqrt{\frac{\left(n_{U}-1\right) S_{U}^{2}+\left(n_{C}-1\right) S_{C}^{2}}{n_{U}+n_{C}-2}}
$$

and

$$
J=1-\frac{3}{4\left(n_{U}+n_{C}-2\right)-1}
$$

where $\overline{X_{U}}$ and $\overline{X_{C}}$ are the mean metal concentration $\left(\mathrm{mg} \mathrm{kg}^{-1}\right.$, dry matter) in parts of willow species growing in uncontaminated (U) and contaminated $(\mathrm{C})$ soils, $\mathrm{nU}$ and $\mathrm{nC}$ are the sample sizes of willow parts from uncontaminated (U) and contaminated (C) soils, and SU and SC are their standard deviations. A negative $\mathrm{g}$ value means higher metal concentration in willow parts growing in contaminated than in uncontaminated soil. We used subgroup meta-analysis to determine whether metal accumulation from contaminated soils was similar among the different parts of the willow species. The four subgroups were the main parts of a willow species (root, stem, twig, and leaf).

We estimated the overall effect, and examined the effects of moderators (willow parts) using random-effects model. Random-effects model was used, because studies were not expected to estimate a common effect size due to variable locations, conditions, experimental setups and methods used in the individual studies [40]. Random-effect models are more plausible than fixed-effect ones and also attribute the distribution of effect sizes to real differences among studies and do not assume sampling error as the only source of differences in effect sizes between studies [40]. The mean effect size was considered statistically significant if the $95 \%$ bootstrap confidence interval (CI; calculated with 999 iterations) did not include zero.

We assessed whether effect sizes were homogenous or varied across studies (i.e., if there was heterogeneity), since if the effect sizes vary across studies, the interpretation of results would be substantially different than in the case of consistent effect sizes. To describe the heterogeneity of effects between studies, complementary measures of heterogeneity, $Q, T^{2}$ and $I^{2}$, were calculated [40]. Using a $Q$-test based on analysis of variance, we partitioned the total variance $\left(Q_{\text {total }}\right)$ into within groups $\left(Q_{\text {within }}\right)$ and between groups $\left(Q_{\text {between }}\right)$ variances. Then, these different components of variance were tested for statistical significance [40]. Significant variance between groups $\left(Q_{\text {between }}\right)$ means that metal accumulation from contaminated soils was significantly different according to the plant parts of willow species. Furthermore, to evaluate the proportion of true variance explained by the covariates (subgroup classification), the $R^{2}$ was calculated [40]. During the calculations, subgroups with less than six cases were excluded from subgroup analyses.

Meta-analyses are often subjected to publication bias resulting in missing studies and potentially biased effect sizes [40]. Therefore, we tested the publication bias by using funnel plots and the Egger's test [40]. In the case of significant asymmetry, the trim and fill method was used [41]. This method calculates the number of missing studies and estimates their effect sizes as well as standard errors. Then, these missing studies are added to the data set of the meta-analysis, and the summary effect size is re-computed. This method yields an unbiased estimate of the summary effect size [40]. Meta-analyses, heterogeneity measures, and assessment of publication bias were completed by the MAd and metafor packages $[42,43]$ operated in the $\mathrm{R}$ version 3.2.4. To assess whether metal accumulation rate in willow parts increased with exposure time, the relationship between the standardized mean difference (Hedges' $g$ ) and the exposure time was examined. We also analysed the correlation between the soil $\mathrm{pH}$ and the accumulation rate of metals. Moreover, to study synergism between metals, the correlation between accumulation rate of metals in a given 
plant part was assessed. The above relationships were investigated by linear models using the $l m$ method implemented in the R.

\section{Results}

\subsection{Literature search}

The literature search yielded 527 publications. Of these, only 8 publications reported mean metal $(\mathrm{Cd}, \mathrm{Pb}$, and $\mathrm{Zn})$ concentrations with standard deviations and sample sizes for contaminated and uncontaminated (control) soils (Supplementary Materials Table A.1). From these publications, 194 comparisons were extracted. In these comparisons, metal concentrations were found to be moderate to high in soils $\left(2.5-67.4 \mathrm{mg} \mathrm{kg}^{-1}\right.$ for $\mathrm{Cd}, 80-2230 \mathrm{mg} \mathrm{kg}^{-1}$ for $\mathrm{Pb}$, and $180-3718 \mathrm{mg} \mathrm{kg}^{-1}$ for $\mathrm{Zn}$ ). Nine willow species and their clones were studied in the selected papers (Supplementary Materials Table A.1). In the selected publications Salix viminalis was studied the most frequently. Trends in metal accumulation rate in plant parts of Salix viminalis were similar to those of all combined willow species (Supplementary Materials Fig. D.1), confirming our decision to analyse all willow species together. Only the effect of soil $\mathrm{pH}$ on the metal accumulation rate could be analysed because data on other soil properties were missing (there were not data with more than five cases).

\subsection{Accumulations of metals in willow tissues}

\subsubsection{Cd accumulation}

All plant parts (root, stem, twig, and leaf) of willow species in contaminated soils accumulated significantly more $\mathrm{Cd}$ compared to those of control individuals growing in uncontaminated soils (Fig. 1 and Supplementary Materials Table B.1-2). Accumulation of Cd did not differ significantly among the plant tissues (root, stem, twig, and leaf; Fig. 1 and Supplementary Materials Table B.1-2). Total heterogeneity in the overall model was significant and there was also significant residual, unexplained heterogeneity (Supplementary Materials Table B.1-2). Both the classical and the random-effects version of the Egger's test revealed significant asymmetry in the funnel plot, however, the trim and fill method estimated 0 missing value (Supplementary Materials C.1).

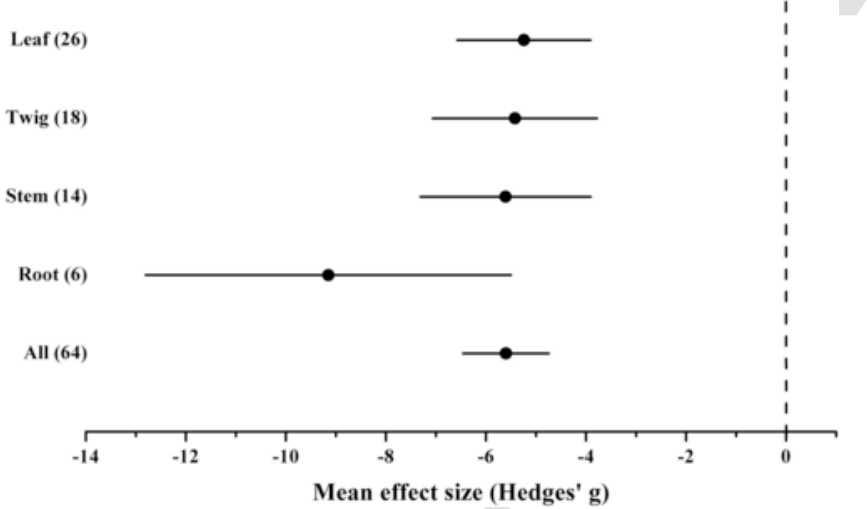

Fig. 1. Mean effect sizes of random-effect models (mean Hedges' $g \pm 95 \%$ confidence interval) for $\mathrm{Cd}$ accumulation in willow parts. Values in brackets refer to the number of comparisons from which the mean effect size was calculated. A negative $g$ value means higher Cd concentration in plant parts of willow species growing on contaminated than uncontaminated sites. The mean effect size was considered statistically significant if the $95 \%$ bootstrap confidence interval $(\mathrm{CI})$ did not include zero.

\subsection{2. $\mathrm{Pb}$ accumulation}

All plant parts (root, stem, twig, and leaf) of willow species in contaminated soils accumulated significantly more $\mathrm{Pb}$ compared to those of control individuals growing in uncontaminated soils (Fig. 2 and Supplementary Materials Table B.3-4). However, significant difference was found among $\mathrm{Pb}$ accumulation of plant parts, since the accumulation rate of $\mathrm{Pb}$ was significantly higher in roots and twigs than in stems and leaves (Fig. 2 and Supplementary Materials Table B.3-4). Both the total and the unexplained heterogeneities were significant (Supplementary Materials Table B.3-4). Both regression tests showed significant funnel plot asymmetries, however, the trim and fill method estimated 0 missing value (Supplementary Materials C.2).

\subsubsection{Zn accumulation}

All plant parts (root, stem, twig, and leaf) of willow species in contaminated soils accumulated significantly more $\mathrm{Zn}$ compared to those of control individuals growing in uncontaminated soils (Fig. 3 and Supplementary Materials Table B.5-6). The accumulation rate of $\mathrm{Zn}$ was significantly different among plant parts, as willow stems ac-

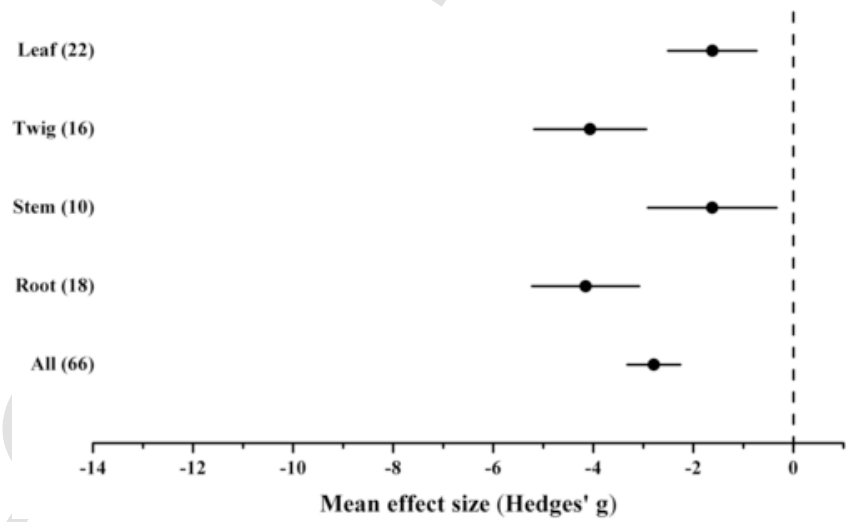

Fig. 2. Mean effect sizes of random-effect models (mean Hedges' $g \pm 95 \%$ confidence interval) for $\mathrm{Pb}$ accumulation in willow parts. Values in brackets refer to the number of comparisons from which the mean effect size was calculated. A negative $g$ value means higher $\mathrm{Pb}$ concentration in plant parts of willow species growing on contaminated than uncontaminated sites. The mean effect size was considered statistically significant if the $95 \%$ bootstrap confidence interval (CI) did not include zero.

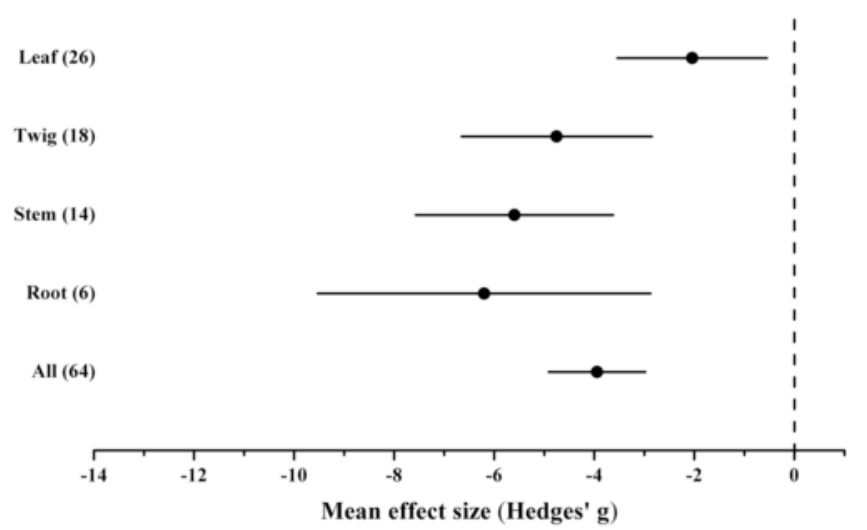

Fig. 3. Mean effect sizes of random-effect models (mean Hedges' $g \pm 95 \%$ confidence interval) for $\mathrm{Zn}$ accumulation in willow parts. Values in brackets refer to the number of comparisons from which the mean effect size was calculated. A negative $g$ value means higher $\mathrm{Zn}$ concentration in plant parts of willow species growing on contaminated than uncontaminated sites. The mean effect size was considered statistically significant if the $95 \%$ bootstrap confidence interval (CI) did not include zero. 
cumulated significantly more Zn compared to leaves (Fig. 3 and Supplementary Materials Table B.5-6). Both the total heterogeneity and the residual, unexplained heterogeneities were significant (Supplementary Materials Table B.5-6). Both regression tests showed significant funnel plot asymmetries, however, the trim and fill method estimated 0 missing value (Supplementary Materials C.3).

\subsection{Correlation between soil $\mathrm{pH}$ and metal accumulations in willows tissues}

Out of the 12 relationships between the soil $\mathrm{pH}$ and the metal $(\mathrm{Cd}$, $\mathrm{Pb}$, and $\mathrm{Zn}$ ) accumulations in willow parts (in root, stem, twig, and leaf), only one relationship was significant. Significant positive relationship was found between the soil $\mathrm{pH}$ and the standardized mean difference (Hedges' $g$ ) calculated for Cd concentrations in stems of willow species growing on contaminated vs. uncontaminated sites (Supplementary Materials Fig. D.2), indicating that the accumulation rate of $\mathrm{Cd}$ in stems was higher as the soil $\mathrm{pH}$ decreased.

\subsection{Correlation between accumulations of metals in willow tissues}

There were sufficient data only for the concentrations of $\mathrm{Cd}$ and $\mathrm{Zn}$ in stems and leaves of willow species. Significant positive relationship between the standardized mean differences (Hedges' $g$ ) calculated for $\mathrm{Cd}$ and $\mathrm{Zn}$ concentrations in stems of willow species growing on contaminated vs. uncontaminated sites was found (Supplementary Materials Fig. D.3).

\subsection{Temporal accumulations of metals in willow tissues}

Analysing the accumulations of $\mathrm{Cd}, \mathrm{Pb}$, and $\mathrm{Zn}$ in willow tissues, three significant time-dependent correlations were found. Accumulation rate of $\mathrm{Cd}$ was increased significantly with exposure time both in twigs and leaves, since the difference in Cd concentrations of twigs and leaves between willow species growing in contaminated vs. uncontaminated soils were increased significantly with exposure time (Figs. 4 and 5). Similarly, the difference in $\mathrm{Zn}$ concentration between

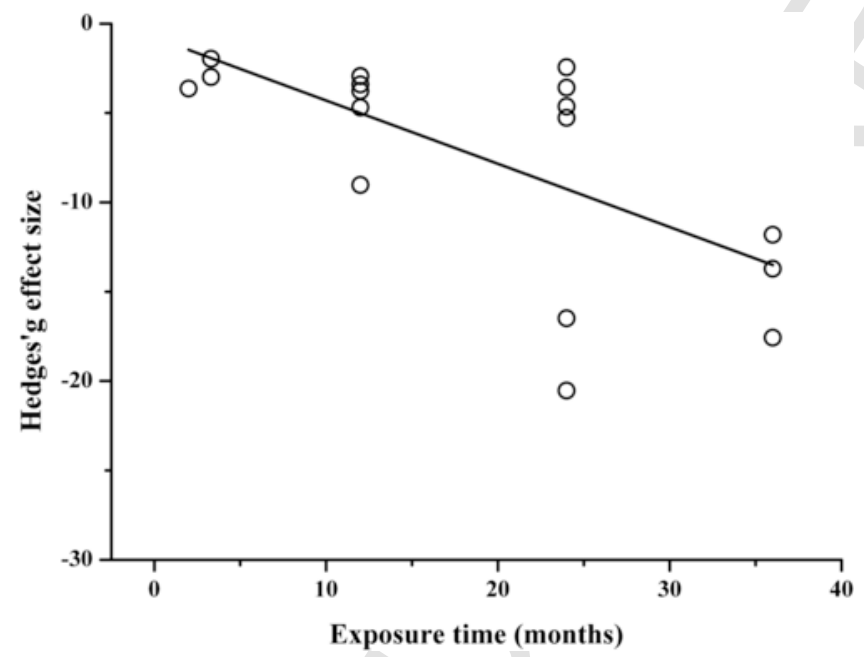

Fig. 4. The relationship between the standardized mean difference (Hedges' $g$ ) calculated for $\mathrm{Cd}$ concentrations in twigs of willow species growing on contaminated vs. uncontaminated sites and the exposure time. More negative $g$ values indicate higher difference in $\mathrm{Cd}$ concentration between the twigs of willow species growing on contaminated vs. uncontaminated sites (linear regression: $\mathrm{F}=11.98, \mathrm{n}=18, \mathrm{p}=0.003, \mathrm{r}=0.39$ ).

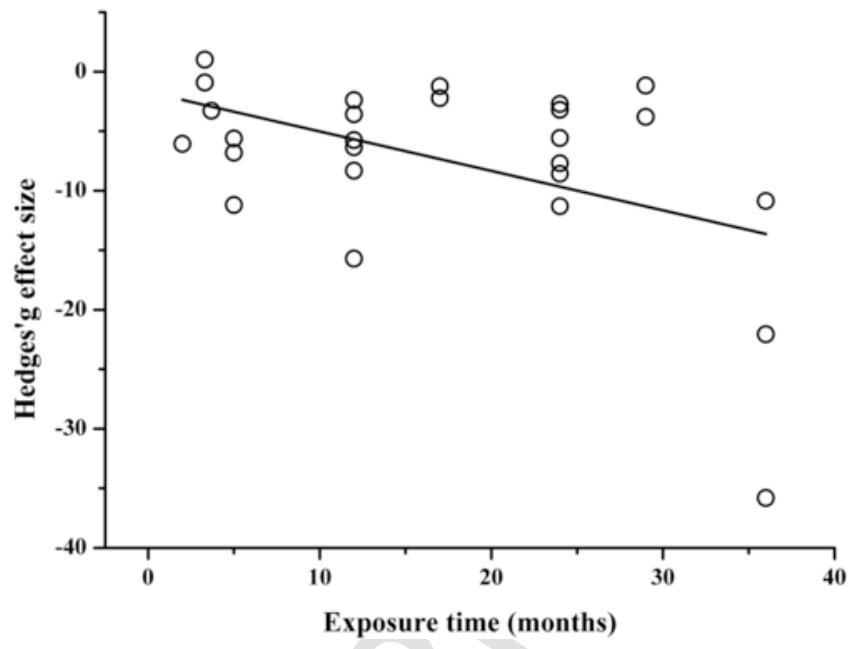

Fig. 5. The relationship between the standardized mean difference (Hedges' $g$ ) calculated for $\mathrm{Cd}$ concentrations in leaves of willow species growing on contaminated vs. uncontaminated sites and the exposure time. More negative $g$ values indicate higher difference in $\mathrm{Cd}$ concentration between the leaves of willow species growing on contaminated vs. uncontaminated sites (linear regression: $\mathrm{F}=6.98, \mathrm{n}=26, \mathrm{p}=0.014, \mathrm{r}=0.19$ ).

the twigs of willow species growing in contaminated vs. uncontaminated soils was increased significantly with exposure time, indicating that $\mathrm{Zn}$ accumulation in twigs tends to increase with time (Fig. 6).

\section{Discussion}

\subsection{Accumulations of metals in willow tissues}

Our results based on meta-analytical methods showed that all plant parts of willow species growing in contaminated soils accumulated significantly more $\mathrm{Cd}, \mathrm{Pb}$, and $\mathrm{Zn}$ compared to those of control individuals growing in uncontaminated soils. However, in some cases, the rate of metal accumulation was significantly different among plant parts.

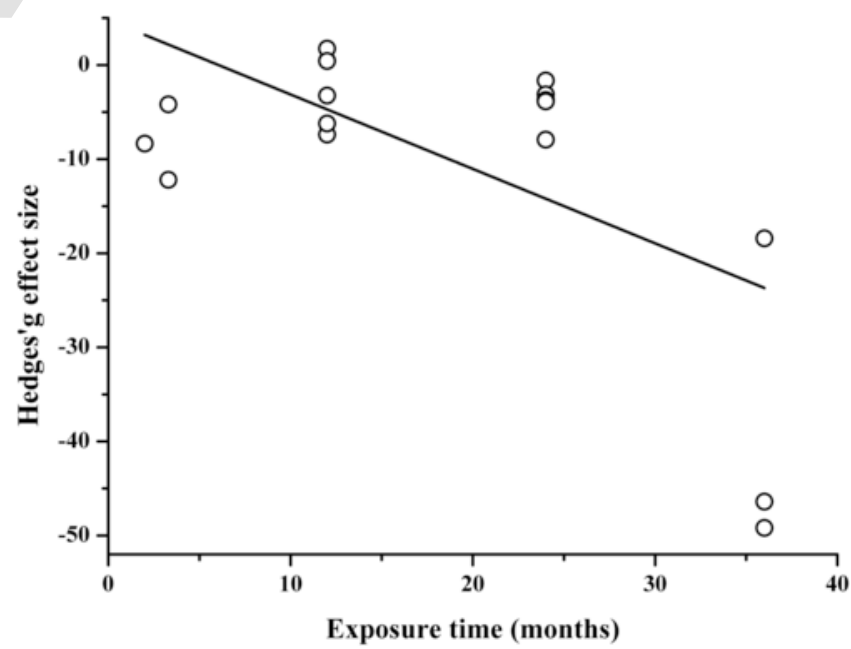

Fig. 6. The relationship between the standardized mean difference (Hedges' $g$ ) calculated for $\mathrm{Zn}$ concentrations in twigs of willow species growing on contaminated vs. uncontaminated sites and the exposure time. More negative $g$ values indicate higher difference in $\mathrm{Zn}$ concentration between the twigs of willow species growing on contaminated vs. uncontaminated sites (linear regression: $\mathrm{F}=8.98, \mathrm{n}=18, \mathrm{p}=0.009, \mathrm{r}=0.32$ ). 
We found that the accumulation of Cd was not significantly different by plant tissues: roots, stems, twigs, and leaves accumulated $\mathrm{Cd}$ in similar concentrations. However, previous studies reported inconsistent results. Wahsha et al. [44] demonstrated that roots of willow species accumulated $\mathrm{Cd}$ in the highest concentration, while lower concentration was found in leaves and even lower in stem tissues, but these differences were not tested statistically. In the cases of several willow clones Lux et al. [26] found that Cd concentration was significantly higher in roots than in the aboveground plant parts. Our results also showed that roots accumulated slightly more $\mathrm{Cd}$ than the other plant parts. Concentration of $\mathrm{Cd}$ was also reported to be higher in roots compared to leaves of willows by both low [45] and moderate [14] soil $\mathrm{Cd}$ concentrations. Vandecasteele et al. [46] found that $\mathrm{Cd}$ concentrations in leaves and roots were similar in willow species growing in moderately contaminated soils, while leaves accumulated more $\mathrm{Cd}$ than roots in species growing in heavily contaminated soils. Furthermore, Bissonnette et al. [13] demonstrated that $\mathrm{Cd}$ concentration was the highest in stems; it was moderate in leaves, and was the lowest in roots of $S$. viminalis. Ling et al. [47] studied the accumulation of Cd in plant parts of $S$. alba trees by low $\left(0.5 \mathrm{mg} \mathrm{kg}^{-1}\right)$, moderate $\left(6 \mathrm{mg} \mathrm{kg}^{-1}\right)$ and high $\left(60 \mathrm{mg} \mathrm{kg}^{-1}\right)$ soil $\mathrm{Cd}$ concentrations. The authors found that $\mathrm{Cd}$ concentration was significantly lower in roots than in leaves of $S$. alba both by low and high soil concentrations. Furthermore, similarly to our findings, significant differences were not indicated between plant parts by moderate soil concentration [48]. It was found in a study by Dos Santos Utmazian and Wenzel [31] that leaves of willows accumulated $\mathrm{Cd}$ in significantly higher concentration than roots. Generally, compartmentalization of metals within trees is considered to be greatly variable by species and clones [15]. Factors influencing the accumulation pattern of $\mathrm{Cd}$ within (among others willow) plants were also assessed by Salt et al. [49] and Vassilev et al. [50]. They found accumulation patterns similar to those in our results and concluded that $\mathrm{Cd}$ distribution and translocation to the aboveground tissues was primarily driven by the transpiration stream. In the aboveground tissues of willows, $\mathrm{Cd}$ is usually sequestered in the vacuoles, by which toxic effects of $\mathrm{Cd}$ can be greatly minimized [51]. Our results on Cd accumulation emphasized that meta-analysis is a powerful statistical approach to summarise the outcomes of several studies with often inconsistent results.

Our results revealed that the accumulation rate of $\mathrm{Pb}$ in willow species was significantly higher in roots and twigs than in stems and leaves. In accordance with our results, Bissonnette et al. [13] also reported that roots accumulated significantly more $\mathrm{Pb}$ than leaves and stems. Cloutier-Hurteau et al. [48] and Kacálková et al. [52] also concluded that the main $\mathrm{Pb}$ depository part of the studied willow species were the roots, since significantly more $\mathrm{Pb}$ was accumulated in roots than in leaves. The same accumulation pattern was observed by Borišev et al. [53] in the cases of four different Salix clones by various levels of $\mathrm{Pb}$ contamination. Mleczek et al. [21] also demonstrated much lower $\mathrm{Pb}$ concentrations in the aboveground plant parts compared to roots of $S$. viminalis. Additionally, our results also demonstrated that willow twig is the other main $\mathrm{Pb}$ accumulator plant part, as roots and twigs accumulated $\mathrm{Pb}$ in similar concentrations. This difference in accumulation rate among willow tissues was most probably caused by the restricted translocation of toxic metals between roots and stems, and between twigs and leaves [54,55]. Restricted translocation of $\mathrm{Pb}$ from roots to stems and leaves can be explained by a metal exclusion mechanism in roots by which plants avoid damages in their photosynthetic processes $[23,53,56]$. Included publications did not assess the role of mycorrhizal associations on metal accumulation; however, it was highlighted that mycorrhizal associations can greatly reduce metal translocation from roots to stems, among others by binding metals on cell wall components or intracellular immobilization [57,58]. Vysloužilová et al. [59] studied the $\mathrm{Pb}$ accumulation in seven different willow clones both by low (29.3 $\left.\mathrm{mg} \mathrm{kg}^{-1}\right)$ and high $\left(2029 \mathrm{mg} \mathrm{kg}^{-1}\right)$ soil $\mathrm{Pb}$ concentrations. In contrast to our results, the authors found higher $\mathrm{Pb}$ concentration in leaves than in twigs of six willow clones by low soil $\mathrm{Pb}$ concentration. However, by high soil $\mathrm{Pb}$ contamination, concentration was higher in leaves than in twigs in three clones, while higher concentration was demonstrated in twigs than in leaves also in three clones [59]. Accumulation pattern of $\mathrm{Pb}$ was also studied by Stanislawska-Glubiak et al. [60], and similarly to our findings, higher $\mathrm{Pb}$ concentrations were found in roots than in twigs in the cases of sand and loess soils. However, in contrast to our results, the highest $\mathrm{Pb}$ concentration was found in leaves in loess soil. Besides these previous, concentration and translocation patterns of $\mathrm{Pb}$ are also widely studied within willows in hydroponics. These results generally emphasize that willows sequester most of the $\mathrm{Pb}$ in roots $[3,61,62]$.

We demonstrated that the rate of $\mathrm{Zn}$ accumulation was different among plant tissues, as willow stems accumulated significantly more $\mathrm{Zn}$ compared to leaves. Contrary to our findings, Maxted et al. [63] and Migeon et al. [64] indicated that the studied willow species accumulated significantly more $\mathrm{Zn}$ in leaves than in stems. Moreover, Hammer and Keller [65] and Kacálková et al. [66] showed that leaves can accumulate significantly more $\mathrm{Zn}$ than twigs and roots of willow species. Różanowski et al. [67] also demonstrated higher Zn concentration in leaves than in stems of $S$. viminalis. Yang et al. [33] investigated the accumulation of $\mathrm{Zn}$ in plant parts of 12 different willow clones, and they demonstrated $\mathrm{Zn}$ concentration in plant parts in decreasing concentration in the following order: leaves $>$ roots $>$ stems. Łukaszewicz et al. [68] also found in S. viminalis that leaves accumulated $\mathrm{Zn}$ in the highest concentration, however, concentration of $\mathrm{Zn}$ was slightly higher directly above the roots than in upper stems. In contrast, Baltrènas and Čepanko [9] demonstrated that Zn concentration was slightly lower in the middle parts than in the bottom parts of willow stems. Besides Pb accumulation, Vysloužilová et al. [59] also studied the $\mathrm{Zn}$ accumulation in seven different willow clones both by low $\left(87.1 \mathrm{mg} \mathrm{kg}^{-1}\right)$ and high $\left(2087 \mathrm{mg} \mathrm{kg}^{-1}\right)$ soil $\mathrm{Zn}$ concentrations. By low soil $\mathrm{Zn}$ concentration, five willow clones accumulated more $\mathrm{Zn}$ in their leaves than in twigs, while only two willow clones accumulated more $\mathrm{Zn}$ in twigs than in leaves. By high soil $\mathrm{Zn}$ concentration, in contrast to our results, each of the seven clones accumulated more $\mathrm{Zn}$ in their leaves compared to twigs. Based on our results it can be highlighted that the $\mathrm{Zn}$ accumulation potential of stems appeared to be unexpectedly prosperous compared to the other plant parts of willows. One of the factors potentially accountant for the $\mathrm{Zn}$ accumulation pattern demonstrated in our study is the seasonal variation of $\mathrm{Zn}$ concentration in stem and leaf [69]. In addition, leaf fall and nutrient availability are also factors resulting in lower $\mathrm{Zn}$ concentration in leaves compared to stems $[15,70]$. Furthermore, co-accumulation with synergistic metals (e.g. Cd) could also contribute to the relatively high $\mathrm{Zn}$ concentration in willow stems [19].

It could be concluded that all plant parts (root, stem, twig, and leaf) of willow species growing in contaminated soils accumulated $\mathrm{Cd}, \mathrm{Pb}$, and $\mathrm{Zn}$ in significantly higher concentrations than those growing in uncontaminated soils. This main finding should be considered during cleaning up contaminated soils with phytoremediation. We recommend that during phytoremediation, attention must be paid to the mechanical removal of roots [71], the one of the main metal-accumulating plant parts of willow species. Without the removal of roots, considerable amount of accumulated metals remain in the soils.

The effect of soil amendments (e.g. manure, red mud, EDTA) on metal mobility in soils and on accumulation in plants have been 
widely studied [72,73]. Application of compost was reported to enhance metal accumulation in plants by modifying soil properties, and by increasing soil microbial activity [74]. Application of compost was reported to promote the growth and enhance the metal accumulation potential of willows as well [75]. In contrast, Maxted et al. [63] did not observe any enhancement in $\mathrm{Cd}$ and $\mathrm{Zn}$ accumulations in willows after sewage sludge application. It was reported that lime and composted biosolid application highly increased $\mathrm{Cd}, \mathrm{Pb}$, and $\mathrm{Zn}$ concentrations, while reduced growth of willows [36]. Our results showed that willows had the inherent potential to accumulate $\mathrm{Cd}, \mathrm{Pb}$, and $\mathrm{Zn}$ in high concentrations. This accumulation potential can be further enhanced by adding appropriate amendments.

\subsection{Correlation between soil $\mathrm{pH}$ and accumulations of metals in willow tissues}

We demonstrated that the $\mathrm{Cd}$ accumulation in willow stems was significantly higher as the soil $\mathrm{pH}$ decreased; suggesting that the more acidic $\mathrm{pH}$ may increase metal mobilization and accumulation in stems. Soil $\mathrm{pH}$ condition is one of the main factors to consider when assessing metal availability [76]. It was reported that metals were more mobile under acidic soil conditions than in neutral and alkaline soils [77]. In accordance with our observations, Wang et al. [78] found that $\mathrm{Cd}$ and $\mathrm{Zn}$ accumulations in Thlaspi caerulescens plants were increased under acidic compared to alkaline soil conditions. Furthermore, McBride [79] demonstrated that alkaline $\mathrm{pH}$ reduces $\mathrm{Cd}$ availability. On the other hand, McBride [79] also found that alkaline $\mathrm{pH}$ reduces $\mathrm{Pb}$ availability as well. In contrast to our findings, Kacálková et al. [52] demonstrated that more alkaline $\mathrm{pH}$ (increase from 6.1 to 7.4) increased the amount of available $\mathrm{Cd}$ in soil. An earlier study from Shuman [80] observed the same phenomenon that was highlighted by Kacálková et al. [52]. Adamczyk-Szabela et al. [81] studied the $\mathrm{Zn}$ accumulation in Valeriana officinalis plants grown in acidic ( $\mathrm{pH} 3.5$ and $\mathrm{pH} 4.1)$, and alkaline (pH 10 and $\mathrm{pH} 13)$ soils. The authors found that $\mathrm{Zn}$ accumulation was decreased in plants grown under alkaline compared to acidic conditions. Additionally, it was reported that accumulations of metals were inhibited in alkaline soils $(\mathrm{pH}>6)$. Plants, however, are able to modify soil $\mathrm{pH}$, thus affecting the availability of metals $[82,83]$.

\subsection{Correlation between accumulations of metals in willow tissues}

Studying the correlation between metals, significant correlation was only found between the concentrations of $\mathrm{Cd}$ and $\mathrm{Zn}$ in stems. The interactions between $\mathrm{Cd}$ and $\mathrm{Zn}$ ions in plants are quite controversial according to relevant studies [24].

Similarly to our results, Dudka et al. [84] also indicated significant positive correlation between the accumulations of $\mathrm{Cd}$ and $\mathrm{Zn}$ in Triticum vulgare plants. Han et al. [19] studied the accumulations of $\mathrm{Cd}$ and $\mathrm{Zn}$, and the correlations between these metals in seven $S$. caprea clones grown in soils with high $\mathrm{Cd}$ concentration alone, with high $\mathrm{Zn}$ concentration alone, and with combined $\mathrm{Cd}$ and $\mathrm{Zn}$ contamination. In accordance with our observations, the authors found that Cd concentration was increased by $110 \%$ in willow stems in the combined ( $\mathrm{Cd}$ and $\mathrm{Zn}$ ) treatment compared to $\mathrm{Cd}$ concentration in stems in the treatment with $\mathrm{Cd}$ alone. In a complementary study with five willow species, enhanced $\mathrm{Cd}$ translocation was observed from roots to leaves in the same combined ( $\mathrm{Cd}$ and $\mathrm{Zn}$ ) treatment compared to the treatment with Cd alone [85]. Also, similarly to our results, Landberg and Greger [86] indicated that the presence of $\mathrm{Cd}$ had positive effect on $\mathrm{Zn}$ accumulation in $S$. viminalis roots. It was also found that the accumulation of $\mathrm{Cd}$ was not influenced by the presence of $\mathrm{Zn}$
[86]. In contrast to our findings, Vassilev et al. [50] observed that $\mathrm{Cd}$ concentration in soil inhibited $\mathrm{Zn}$ accumulation in willows. Han et al. [19] also reported that $\mathrm{Zn}$ concentration was decreased by $61 \%$ in stems of $S$. caprea in the combined ( $\mathrm{Cd}$ and $\mathrm{Zn}$ ) treatment compared to stem $\mathrm{Zn}$ concentration in the treatment with $\mathrm{Zn}$ alone. In a complementary study with five willow species it was observed that the translocation of $\mathrm{Zn}$ was inhibited from roots to leaves in the same combined $(\mathrm{Cd}$ and $\mathrm{Zn})$ treatment compared to the treatment with $\mathrm{Zn}$ alone [85]. Xu et al. [87] also concluded that high Cd concentration of soil inhibited the accumulation of $\mathrm{Zn}$ in Vetiveria zizanioides tissues. Furthermore, Hart et al. [88] reported that Cd accumulations in two crop plants (Triticum aestivum and Triticum turgidum) were inhibited by the presence of soil $\mathrm{Zn}$, while $\mathrm{Zn}$ accumulations were also inhibited by the presence of soil $\mathrm{Cd}$, indicating a general antagonism between these metals. Earlier studies demonstrated that simultaneous accumulations of $\mathrm{Cd}$ and $\mathrm{Zn}$ in plants can be increased by adding chelating agents to soils, such as EDTA and DTPA $[63,87,89,90]$. Our paper aimed at studying inherent metal accumulations of willows; however, the studies on metal accumulations by adding chemicals are also necessary parts of remediation analyses.

\subsection{Temporal accumulation of metals in willow tissues}

The effect of exposure time (duration of experiment) was quite variable among studies on different plant parts. Considering the total number (12) of potential cases, significant correlation was proven between metal accumulation and exposure time in only three cases.

In our study, increasing accumulation of $\mathrm{Cd}$ was shown both in leaves and twigs of willow species exposed to elevated Cd concentration for a longer time. Contrary, Wieshammer et al. [6], studying $\mathrm{Cd}$ accumulation in leaves of four willow species in a 3-year long experiment, found that $\mathrm{Cd}$ accumulation was decreased from year to year. They concluded that this decreasing trend of accumulation was corresponded to the decreasing amount of available $\mathrm{Cd}$ in the soil. However, similarly to our results, in a 3-year long study French et al. [91] also found that $\mathrm{Cd}$ concentration was increased in leaves of all the five studied willow species from the second to the third year of the experiment. Experiments studying $\mathrm{Cd}$ accumulation in willow twigs are very limited $[52,60]$, in addition none of these studied the temporal trend of accumulation.

In our study, there was no significant relationship between the accumulation rate of $\mathrm{Pb}$ in willow tissues and the exposure time. There are only a few studies reporting information on $\mathrm{Pb}$ accumulation in willow parts related to exposure time. In a 4-year long study, Zárubová et al. [92] found that concentration of $\mathrm{Pb}$ in wood tissues was increased by the second year, was slightly decreased by the third year and was increased again by the fourth year of the experiment. Ruttens et al. [39] also showed variations in the accumulation of $\mathrm{Pb}$ in leaves of seven willow species. They found that two species had significantly increasing; two had barely increasing, while three species had decreasing concentrations in tissues from the second to the third growing season. Based on the above, it seems that $\mathrm{Pb}$ accumulation in willow parts can be varied greatly with exposure time.

Our results indicated that $\mathrm{Zn}$ accumulation in twigs was tended to increase with time, as the difference in $\mathrm{Zn}$ concentration between the twigs of willow species growing in contaminated vs. uncontaminated soils was increased significantly with exposure time. Other studies (that were not involved in our meta-analysis) evaluating temporal accumulation rate of $\mathrm{Zn}$ in willow twigs are missing. However, Rosselli et al. [37], studying accumulation rate of $S$. viminalis, reported that leaves and stems accumulated significantly more $\mathrm{Zn}$ after 8 months of the plantation than did after 3 months. They found, that accumula- 
tion rate of $\mathrm{Zn}$ in roots was also increased, but not significantly. Similarly, Mleczek et al. [93] found that willow roots accumulated more and more $\mathrm{Zn}$ with time. Similar to earlier studies [37,93] our results also suggest that $\mathrm{Zn}$ accumulation in willow parts seems to be increased with time.

Despite the relatively fast growth of willow species, it seems that dilution effect (when intensity of biomass production exceeds the intensity of metal accumulation, resulting in decreasing metal concentrations in concerned plant parts) does not occur during their metal accumulation [55], as significantly increased accumulation rate of $\mathrm{Cd}$ in leaves and twigs, and $\mathrm{Zn}$ in twigs were shown with exposure time. Although, we did not observe any significant correlations in most cases ( 9 cases) of the metal-plant part relationships, there are studies showing temporal changes of $\mathrm{Cd}$ and $\mathrm{Zn}$ accumulation in willow tissues $[91,94]$. In the cases of accumulation rate of $\mathrm{Cd}$ in leaves and twigs, and $\mathrm{Zn}$ in twigs we could not identify saturation point, indicating that metal accumulations were continuous until the end of the 36-month long period. Accumulation capacity of willow species was also investigated for longer time periods. In a decades-long experiment Riddell-Black [95] concluded that to reduce metal concentrations in a heavily contaminated soil to a target concentration, willows should be left growing in highly contaminated soils over 30 years. Similarly, Ostman [96] pointed out that willow plantations need at least 20 years to decrease soil concentration from high to low, assuming constant extraction rate. However, the decontamination of moderately contaminated soils could be achieved in a reasonable timescale (3-5 years) if willows cultivated in short rotation [15]. In addition, Mertens et al. [69] found that after 4 and 6 years from establishment of willow plantation, leaf and stem tissues had significantly lower $\mathrm{Cd}$ and $\mathrm{Zn}$ concentrations than after the first and second years of the experiment. As the success of phytoextraction by willow species depends on both the accumulation rate of the plant parts and the accumulation rate over the time period [97], based on our results, we suggest that willow plantation should be left growing in contaminated soils for at least 3 years, especially when cost-efficiency and enhanced metal extraction are of particular importance. Of course, for phytoremediation purposes, willow plantations could be effectively grown for even much more than 3 years, as some willow parts could be practicable depositories for heavy metals even after decades [98].

We showed that all willow parts accumulated the studied metals $(\mathrm{Cd}, \mathrm{Pb}$, and $\mathrm{Zn})$ significantly, and metal accumulation in certain harvestable tissues was continuous for 36 months. Although the covariates (classification of willow parts) accounted for a considerable proportion of the true variance, there remained significant unexplained heterogeneity in all models. Moreover, the variance explained by the covariates (classification based on plant parts) was also low, indicating the importance of other factors on metal accumulation. This heterogeneity could arise from differences in study regions, study designs and methods applied in the individual studies. Besides the importance of the different plant parts identified in our study, other inherent features of metal accumulation (e.g. concentrations, forms and available amount of metals in the contaminated soil [20,52], soil type and other soil properties $[21,99]$, interactions between soil properties and metals $[100,101]$, types of willow clones [1,31], growth stage of species [63], plant density [102], and time of exposure $[22,69]$ could also contribute to heterogeneity. Therefore, all of the abovementioned essential factors must be considered in a global meta-analysis on phytoremediation.

\section{Conclusions}

Based on the results of our meta-analysis we highlight as a novel observation that willows were capable of accumulating $\mathrm{Pb}$ in high concentrations also in twigs. Furthermore, besides leaves, stems of willows also appeared to be successful $\mathrm{Cd}$ accumulators. Accumulation rates of $\mathrm{Cd}$ and $\mathrm{Zn}$ were high until 36 months, meaning that willows are successful accumulators of these metals in such a time scale. Significant effect of soil $\mathrm{pH}$ on $\mathrm{Cd}$ accumulation in stems was also demonstrated, but influence was not found in the cases of other metals and plant parts. This indicated that metal accumulation was universally not dependent on soil $\mathrm{pH}$ within the studied soil $\mathrm{pH}$ range $(\mathrm{pH}$ 5.3-8.2). Significant positive correlation was found between the accumulations of $\mathrm{Cd}$ and $\mathrm{Zn}$ in willow stems, suggesting that stem is a useful plant part in phytoremediation of soils with simultaneous $\mathrm{Cd}$ and $\mathrm{Zn}$ contamination. Considering our results we recommend that during phytoremediation attention must be paid to the removal of roots at the end of the remediation process, since without the removal of roots considerable amount of accumulated metals remain in the soils. Furthermore, to exploit the inherent metal accumulation potential of willows, we suggest that willow individuals should be left growing for at least 3 years in the contaminated soils, knowing that metal accumulations are continuous and intensive in such a time scale. Additionally, it is highly required to conduct long term (3-10 years) studies in order to assess long term metal accumulation potential and the time scale of economical applicability of willows more thoroughly. However, the successful growing of willows, and therefore metal accumulation rates, are functions of several factors that should also be addressed in further studies.

\section{Acknowledgements}

This work was supported by the SROP4.2.2.B15/1/ KONV20150001 project, financed by the European Union and the European Social Fund. Authorship is by the "sequence by credit" (SDC) principle.

\section{Appendix A. Supplementary data}

Supplementary data associated with this article can be found, in the online version, at http://dx.doi.org/10.1016/j.jhazmat.2017.03.068.

\section{References}

[1] M. Zacchini, F. Pietrini, G. Scarascia Mugnozza, V. Iori, L. Pietrosanti, A. Massacci, Metal tolerance, accumulation and translocation in poplar and willow clones treated with cadmium in hydroponics, Water Air Soil Poll. 197 (2009) 23-34.

[2] B.H. Robinson, S. Bischofberger, A. Stoll, D. Schroer, G. Furrer, S. Roulier, A. Gruenwald, W. Attinger, R. Schulin, Plant uptake of trace elements on a Swiss military shooting range: uptake pathways and land management implications, Environ. Pollut. 153 (2008) 668-676.

[3] O.P. Zhivotovsky, J.A. Kuzovkina, C.P. Schulthess, T. Morris, D. Pettinelli, M. Ge, Hydroponic screening of willows (Salix L.) for lead tolerance and accumulation, Int. J. Phytoremediat. 13 (2010) 75-94.

[4] K. Page, M.J. Harbottle, P.J. Cleall, T.R. Hutchings, Heavy metal leaching and environmental risk from the use of compost-like output as an energy crop growth substrate, Sci. Total Environ. 487 (2014) 260-271.

[5] Y. Liu, Z. Ma, J. Lv, Identifying sources and hazardous risks of heavy metals in topsoils of rapidly urbanizing East China, J. Geogr. Sci. 26 (2016) 735-749.

[6] G. Wieshammer, R. Unterbrunner, T. Bañares García, M.F. Zivkovic, M. Puschenreiter, W.W. Wenzel, Phytoextraction of Cd and $\mathrm{Zn}$ from agricultural soils by Salix ssp. and intercropping of Salix caprea and Arabidopsis halleri, Plant Soil 298 (2007) 255-264. 
[7] L. Kacálková, P. Tlustoš, J. Száková, Phytoextraction of cadmium, copper, zinc and mercury by selected plants, Plant Soil Environ. 55 (2009) 295-304

[8] D.E. Salt, R.D. Smith, I. Raskin, Phytoremediation, Annu. Rev. Plant Phys. 49 (1998) 643-668.

[9] P. Baltrėnas, V. Čepanko, Accumulation of heavy metals in short-rotation willow, Ekologija 55 (2009) 153-163.

[10] S. Vondráčková, P. Tlustoš, J. Száková, Effect of rock phosphate on Zn and Fe bioavailability and accumulation by Salix smithiana in heavily contaminated soil, E3S Web of Conferences, Proceedings of the 16th International Conference on Heavy Metals in the Environment (ICHMET) (2013).

[11] R.L. Chaney, M. Malik, Y.M. Li, S.L. Brown, E.P. Brewer, J.S. Angle, A.J. Baker, Phytoremediation of soil metals, Curr. Opin. Biotechnol. 8 (1997) 279-284.

[12] N.M. Dickinson, Strategies for sustainable woodland on contaminated soils, Chemosphere 41 (2000) 259-263.

[13] L. Bissonnette, M. St-Arnaud, M. Labrecque, Phytoextraction of heavy metals by two Salicaceae clones in symbiosis with arbuscular mycorrhizal fungi during the second year of a field trial, Plant Soil 332 (2010) 55-67.

[14] M. Borišev, S. Pajević, N. Nikolić, B. Krstić, M. Župunski, M. Kebert, A. Pilipović, S. Orlović, Response of Salix alba L. to heavy metals and diesel fuel contamination, Afr. J. Biotechnol. 11 (2012) 14313-14319.

[15] I.D. Pulford, C. Watson, Phytoremediation of heavy metal-contaminated land by trees-a review, Environ. Int. 29 (2003) 529-540.

[16] J.A. González-Oreja, M.A. Rozas, I. Alkorta, C. Garbisu, Dendroremediation of heavy metal polluted soils, Rev. Environ. Health 23 (2008) 223-234.

[17] (Interstate TechnologyITRC (Interstate Technology \& Regulatory Council), Phytotechnology Technical and Regulatory Guidance and Decision Trees, Revised. PHYTO-3, Interstate Technology \& Regulatory Council, Phytotechnologies Team, Washington, D.C, 2009. Tech Reg Update.

[18] B.A. Wani, A. Khan, R.H. Bodha, Salix: A viable option for phytoremediation, Afr. J. Environ. Sci. Technol. 5 (2011) 567-571.

[19] S. Han, D. Kim, J. Lee, Cadmium and zinc interaction and phytoremediation potential of seven Salix caprea clones, J. Ecol. Environ. 33 (2010) 245-251.

[20] A.J.M. Baker, R.R. Brooks, Terrestrial higher plants which hyperaccumulate metallic elements - a review of their distribution, ecology and phytochemistry, Biorecovery 1 (1989) 81-126.

[21] M. Mleczek, Z. Magdziak, I. Rissmann, P. Golinski, Effect of different soil conditions on selected metal accumulation by Salix viminalis tissues, J. Environ. Sci. Heal. A 44 (2009) 1609-1616.

[22] L. Deng, Z. Li, J. Wang, H. Liu, N. Li, L. Wu, P. Hu, Y. Liu, P. Christie, Long-term field phytoextraction of zinc/cadmium contaminated soil by Sedum plumbizincicola under different agronomic strategies, Int. J. Phytoremediat. 18 (2016) 134-140.

[23] A.J.M. Baker, Accumulators and excluder-strategies in the response of plants to heavy metals, J. Plant Nutr. 3 (1981) 643-654.

[24] J.P. Bedell, X. Capilla, C. Giry, C. Schwartz, J.L. Morel, Y. Perrodin, Distribution, movement and availability of $\mathrm{Cd}$, and $\mathrm{Zn}$ in a dredged sediment cultivated with Salix alba, Environ. Exp. Bot. 67 (2009) 403-414.

[25] F. Zarinkamar, Z. Saderi, S. Soleimanpour, Excluder strategies in response to $\mathrm{Pb}$ toxicity in Matricaria chamomilla, Environ. Ecol. Res. 1 (2013) 1-11.

[26] A. Lux, A. Šottníková, J. Opatrná, M. Greger, Differences in structure of adventitious roots in Salix clones with contrasting characteristics of cadmium accumulation and sensitivity, Physiol. Plantarum 120 (2004) 537-545.

[27] N. Mganga, M.L.K. Manoko, Z.K. Rulangaranga, Classification of plants according to their heavy metal content around North Mara Gold Mine, Tanzania: implication for phytoremediation, Tanz. J. Sci. 37 (2011) 109-119.

[28] I.V. Seregin, A.D. Kozhevnikova, N.V. Zhukovskaya, H. Schat, Cadmium tolerance and accumulation in excluder Thlaspi arvense and various accessions of hyperaccumulator Noccaea caerulescens, Russ. J. Plant Physl+ 62 (2015) 837-846.

[29] T. Punshon, N.M. Dickinson, N.W. Lepp, The potential of Salix clones for bioremediating metal polluted soil, in: I. Glimmerveen (Ed.), Heavy Metals and Trees, Proceedings of a Discussion Meeting, Institute of Chartered Foresters, Glasgow, Edinburgh, 1996, pp. 93-104.

[30] B.H. Robinson, T.M. Mills, D. Petit, L. Fung, S.R. Green, B.E. Clothier, Natural and induced cadmium-accumulation in poplar and willow: implications for phytoremediation, Plant Soil 227 (2000) 301-306.

[31] M.N. Dos Santos Utmazian, W.W. Wenzel, Cadmium and zinc accumulation in willow and polar species grown on polluted soils, J. Plant Nutr. Soil Sc. 170 (2007) 265-272.

[32] R. Unterbrunner, M. Puschenreiter, P. Sommer, G. Wieshammer, P. Tlustoš, M. Zupan, W.W. Wenzel, Heavy metal accumulation in trees growing on contaminated sites in Central Europe, Environ. Pollut. 148 (2007) 107-114.

[33] W.D. Yang, Y.Y. Wang, F.L. Zhao, Z.L. Ding, X.C. Zhang, Z.Q. Zhu, X.E. Yang, Variation in copper and zinc tolerance and accumulation in 12 willow clones: implications for phytoremediation, J. Zhejiang Univ.-Sc. B 15 (2014) 788-800.
[34] B. Sylvain, M. Motelica-Heino, F. Miard, E. Joussein, M. Soubrand, B. Sylvain, D. Morabito, Phytostabilization of $\mathrm{As}, \mathrm{Sb}$ and $\mathrm{Pb}$ by two willow species (S. viminalis and S. purpurea) on former mine technosols, Catena 136 (2016) $44-52$.

[35] M. Vysloužilová, P. Tlustoš, J. Száková, Cadmium and zinc phytoextraction potential of seven clones of Salix spp. planted on heavy metal contamination, Plant Soil Environ. 49 (2003) 542-547.

[36] M.J. Boyter, J.E. Brummer, W.C. Leininger, Growth and metal accumulation of geyer and mountain willow grown in topsoil versus amended mine tailings, Water Air Soil Poll. 198 (2009) 17-29.

[37] W. Rosselli, K. Keller, K. Boschi, Phytoextraction capacity of trees growing on a metal contaminated soil, Plant Soil 256 (2003) 265-272.

[38] P. Tlustoš, J. Száková, M. Vysloužilová, D. Pavlíková, J. Weger, H. Javorská, Variation in the uptake of arsenic, cadmium, lead, and zinc by different species of willows Salix spp. grown in contaminated soils, Cent. Eur. J. Biol. 2 (2007) 254-275.

[39] A. Ruttens, J. Boulet, N. Weyens, K. Smeets, K. Adriaensen, E. Meers, S. van Slycken, F.M.G. Tack, L. Meiresonne, T. Thewys, N. Witters, R. Carleer, J. Dupae, J. Vangronsveld, Short rotation coppice culture of willows and poplars as energy crops on metal contaminated agricultural soils, Int. J. Phytoremediat. 13 (2011) 194-207.

[40] M. Borenstein, L.V. Hedges, J.P.T. Higgins, H.R. Rothstein, Introduction to Meta-analysis, John Wiley \& Sons, Ltd, Chichester, UK, 2009.

[41] S. Duval, R. Tweedie, Trim and fill: a simple funnel-plot-based method of testing and adjusting for publication bias in meta-analysis, Biometrics 56 (2000) 455-463.

[42] W. Viechtbauer, Conducting meta-analyses in R with the metafor package, J Stat. Softw. 36 (2010) 1-48

[43] A.C. Del Re, W.T. Hoyt, MAd: Meta-analysis with Mean with Mean Differences. R Package Version 0. 8-2, 2014. http://cran.r-project.org/web/packages/ MAd.

[44] M. Wahsha, C. Bini, E. Argese, F. Minello, S. Fontana, H. Wahsheh, Heavy metals accumulation is willows growing on Spolic Technosols from the abandoned Imperina Valley mine in Italy, J. Geochem. Explor. 123 (2012) 19-24.

[45] M. Vaculík, C. Konlechner, I. Langer, W. Adlassnig, M. Puschenreiter, A. Lux, M.T. Hauser, Root anatomy and element distribution vary between two Salix caprea isolates with different $\mathrm{Cd}$ accumulation capacities, Environ. Pollut. 163 (2012) 117-126.

[46] B. Vandecasteele, E. Meers, P. Vervaeke, B. De Vos, P. Quataert, F.M.G. Tack, Growth and trace metal accumulation of two Salix clones on sediment-derived soils with increasing contamination levels, Chemosphere 58 (2005) 995-1002.

[47] T. Ling, R. Jun, Y. Fangke, Effect of cadmium supply levels to cadmium accumulation by Salix, Int. J. Environ. Sci. Technol. 8 (2011) 493-500.

[48] B. Cloutier-Hurteau, M.-C. Turmel, C. Mercier, F. Courchesne, The sequestration of trace elements by willow (Salix purpurea) - which soil properties favor uptake and accumulation?, Environ. Sci. Pollut. R 21 (2013) 4759-4771.

[49] D.E. Salt, R.C. Prince, I.J. Pickering, I. Raskin, Mechanism of cadmium mobility and accumulation in Indian mustard, Plant Physiol. 109 (1995) 1427-1433.

[50] A. Vassilev, A. Perez-Sanz, B. Semane, R. Carleer, J. Vangronsveld, Cadmium accumulation and tolerance of two Salix genotypes hydroponically grown in presence of cadmium, J. Plant Nutr. 28 (2005) 1-19.

[51] J. Yang, K. Li, W. Zheng, H. Zhang, X. Cao, Y. Lan, C. Yang, C. Li, Characterization of early transcriptional responses to cadmium in the root and leaf of Cd-resistant Salix matsudana Koidz, BMC Genomics 16 (2015) 705.

[52] L. Kacálková, P. Tlustoš, J. Száková, Chromium, nickel, cadmium, and lead accumulation in maize, sunflower, willow, and poplar, Pol. J. Environ. Stud. 23 (2014) 753-761.

[53] M. Borišev, S. Pajević, N. Nikolić, A. Pilipović, B. Krstić, S. Orlović, Phytoextraction of $\mathrm{Cd}, \mathrm{Ni}$, and $\mathrm{Pb}$ using four willow clones (Salix spp.), Pol. J. Environ. Stud. 18 (2009) 553-561.

[54] H. Dahmani-Muller, F. van Oort, B. Gélie, M. Balabane, Strategies of heavy metal uptake by three plant species growing near a metal smelter, Environ. Pollut. 109 (2000) 231-238.

[55] A. Brekken, E. Steinnes, Seasonal concentrations of cadmium and zinc in native pasture plants: consequences for grazing animals, Sci. Total Environ. 326 (2004) 181-195.

[56] E. Stoltz, M. Greger, Accumulation properties of $\mathrm{As}, \mathrm{Cd}, \mathrm{Cu}, \mathrm{Pb}$ and $\mathrm{Zn}$ by four wetland plant species growing on submerged mine tailings, Environ. Exp. Bot. 47 (2002) 271-280.

[57] S. De Maria, A.R. Rivelli, M. Kuffner, A. Sessitsch, W.W. Wenzel, M. Gorfer, J. Strauss, M. Puschenreiter, Interactions between accumulations of trace elements and major nutrients in Salix caprea after inoculation with rhizosphere microorgaisms, Chemosphere 84 (2011) 1256-1261.

[58] C. Leyval, K. Turnau, K. Haselwandter, Effect of heavy metal pollution in mycorrhizal colonization and function: physiological, ecological and applied aspects, Mycorrhiza 7 (1997) 139-153. 
[59] M. Vysloužilová, P. Tlustoš, J. Száková, D. Pavlíková, As, Cd Pb and Zn uptake by Salix spp. clones grown in soils enriched by high loads of these elements, Plant Soil Environ. 49 (2003) 191-196.

[60] E. Stanislawska-Glubiak, J. Korzeniowska, A. Kocoń, Effect of reclamation of heavy metal contaminated soil on growth of energy willow, Pol. J. Environ. Stud. 21 (2012) 187-192.

[61] J. Malá, H. Cvrčková, P. Máchová, J. Dostál, P. Šíma, Heavy metal accumulation by willow clones in short-time hydroponics, J. For. Sci. 56 (2010) 28-34

[62] S. Wang, X. Shi, H. Sun, Y. Chen, H. Pan, X. Yang, T. Rafiq, Variations in metal tolerance and accumulation in three hydroponically cultivated varieties of Salix integra treated with lead, PLoS One 9 (2014) e108568.

[63] A.P. Maxted, C.R. Black, H.M. West, N.M.J. Crout, S.P. McGrath, S.D Young, Phytoextraction of cadmium and zinc by Salix from soil historically amended with sewage sludge, Plant Soil 290 (2007) 157-172.

[64] A. Migeon, P. Richaud, F. Guinet, M. Chalot, D. Blaudez, Metal accumulation by woody species on contaminated sites in the North of France, Water Air Soil Poll. 204 (2009) 89-101.

[65] D. Hammer, C. Keller, Changes in the rhizosphere of metal-accumulating plants evidenced by chemical extractants, J. Environ. Qual. 31 (2002) 1561-1569.

[66] L. Kacálková, P. Tlustoš, J. Száková, Phytoextraction of risk elements by willow and poplar trees, Int. J. Phytoremediat. 17 (2015) 414-421.

[67] B. Różanowski, M. Michałowski, B. Tora, V. Cablik, L. Cernotova, Effectiveness of the use of willows tree (Salix viminalis) for wastewater treatment, AGH J. Min. Geoeng. 36 (2012) 159-165.

[68] J.P. Łukaszewicz, R.P. Wesołowski, A. Cyganiuk, Enrichment of Salix viminalis wood in metal ions by means of phytoextraction, Pol. J. Environ. Stud. 18 (2009) 507-511.

[69] J. Mertens, P. Vervaeke, E. Meers, F.M.G. Tack, Seasonal changes of metals in willow (Salix sp.) stands for phytoremediation on dredged sediment, Envir. Sci. Tech. 40 (2006) 1962-1968.

[70] M.L. Sander, T. Ericsson, Vertical distributions of plant nutrients and heavy metals in Salix viminalis stems and their implications for sampling, Biomass Bioenerg. 14 (1998) 57-66.

[71] I. Dimitriou, D. Rutz, Sustainable short rotation coppice, A Handbook, WIP Renewable Energies, Munich, Germany, 2015.

[72] C.W.A. Nascimento, B. Xing, Phytoextraction: a review on enhanced metal availability and plant accumulation, Sci. Agric. (Piracicaba, Braz.) 63 (2006) 299-311.

[73] Y. Hua, K.V. Heal, W. Friesl-Hanl, The use of red mud as an immobiliser for metal/metalloid-contaminated soil: a review, J. Hazard. Mater. 325 (2017) 17-30.

[74] A.M. Taiwo, A.M. Gbadebo, J.A. Oyedepo, Z.O. Ojekunle, O.M. Alo, A.A Oyeniran, O.J. Onalaja, D. Ogunjimi, O.T. Taiwo, Bioremediation of industrially contaminated soil using compost and plant technology, J. Hazard. Mater. 304 (2016) 166-172.

[75] T. Abedi, S. Moghaddami, E. Lashkar Bolouki, Growth of Populus and Salix species under compost leachate irrigation, Ecol. Balk. 6 (2014) 57-65.

[76] R.D. Harter, Effect of soil pH on adsorption of lead, copper, zinc, and nickel, Soil Sci. Soc. Am. J. 47 (1983) 47-51.

[77] D.L. Jensen, P.E. Holm, T.H. Christensen, Soil and groundwater contamination with heavy metals at two scrap iron and metal recycling facilities, Waste Manage. Res. 18 (2000) 52-63.

[78] A.S. Wang, J.S. Angle, R.L. Chaney, T.A. Delorme, R.D. Reeves, Soil pH effects on uptake of Cd and Zn by Thlaspi caerulescens, Plant Soil 281 (2006) 325-337.

[79] M.B. McBride, Toxic metals in sewage sludge-amended soils: has promotion of beneficial use discounted the risk?, Adv. Environ. Res. 8 (2003) 5-19.

[80] L.M. Shuman, Fractionation method for soil microelements, Soil Sci. 140 (1985) 11-22.

[81] D. Adamczyk-Szabela, J. Markiewicz, W.M. Wolf, Heavy metal uptake by herbs. IV. Influence of soil $\mathrm{pH}$ on the content of heavy metals in Valeriana officinalis L, Water Air Soil Poll. 226 (2015) 106.

[82] A. Fritioff, M. Greger, Aquatic and terrestrial plant species with potential to remove heavy metals from stormwater, Int. J. Phytoremediat. 3 (2003) 211-224.
[83] B.V. Tangahu, S.R. Sheikh Abdullah, H. Basri, M. Idris, N. Anuar, M. Mukhlisin, A review on heavy metals ( $\mathrm{As}, \mathrm{Pb}$, and $\mathrm{Hg}$ ) uptake by plants through phytoremediation, Int. J. Chem. Eng. (2011). Article ID 939161

[84] S. Dudka, M. Piotrowska, A. Chlopecka, Effect of elevated concentrations of $\mathrm{Cd}$ and $\mathrm{Zn}$ in soil on spring wheat yield and the metal contents of the plants, Water Air Soil Poll. 76 (1994) 333-341.

[85] S. Han, D. Kim, S. Shin, Bioaccumulation and physiological response of five willows to toxic levels of cadmium and zinc, Soil Sediment Contam. 22 (2013) 241-255.

[86] T. Landberg, M. Greger, Interclonal variation of heavy metal interactions in Salix viminalis, Environ. Toxicol. Chem. 21 (2002) 2669-2674.

[87] W. Xu, W. Li, J. He, S. Balwant, Z. Xiong, Effects of insoluble Zn Cd, and EDTA on the growth, activities of antioxidant enzymes and uptake of $\mathrm{Zn}$ and Cd in Vetiveria zizanioides, J. Environ. Sci. China 21 (2009) 186-192.

[88] J.J. Hart, R.M. Welch, W.A. Norvell, L.V. Kochian, Transport interactions between cadmium and zinc in roots of bread and durum wheat seedlings, Physiol. Plant. 116 (2002) 73-78.

[89] W.H. Xu, H.X. Wang, H. Liu, Z.T. Xiong, B. Singh, Effects of zinc, cadmium and their combined pollution on nutrient uptake and $\mathrm{Zn}, \mathrm{Cd}$ accumulation in ryegrass (Lolium perenne L.), Asian J. Ecotoxicol. 1 (2006) 70-74.

[90] H. Zhao, L. Lin, Q. Yan, Y. Yang, X. Zhu, J. Shao, Effects of EDTA and DTPA on lead and zinc accumulation of rygrass, J. Environ. Prot. 2 (2011) 932-939.

[91] C.J. French, N.M. Dickinson, P.D. Putwain, Woody biomass phytoremediation of contaminated brownfield land, Environ. Pollut. 141 (2006) 387-395.

[92] P. Zárubová, M. Hejcman, S. Vondráčková, L. Mrnka, J. Száková, P. Tlustoš, Distribution of $\mathrm{P}, \mathrm{K}, \mathrm{Ca}, \mathrm{Mg}, \mathrm{Cd}, \mathrm{Cu}, \mathrm{Fe}, \mathrm{Mn}, \mathrm{Pb}$ and $\mathrm{Zn}$ in wood and bark age classes of willows and poplars used for phytoextraction on soils contaminated by risk elements, Environ. Sci. Pollut. R22 (2015) 18801-18813.

[93] M. Mleczek, M. Łukaszewski, Z. Kaczmarek, I. Rissmann, P. Golinski, Efficiency of selected heavy metals accumulation by Salix viminalis roots, Environ. Exp. Bot. 65 (2009) 48-53.

[94] D. Hammer, A. Kayser, C. Keller, Phytoextraction of Cd and Zn with Salix viminalis in field trials, Soil Use Manage. 19 (2003) 187-192.

[95] D. Riddell-Black, A Review of the Potential for the Use of Trees in the Rehabilitation of Contaminated Land, WRc Report CO 3467, Water Research Centre, Medmenham, 1993

[96] G. Ostman, Cadmium in Salix-a study of the capacity of Salix to remove cadmium from arable soils, in: P. Aronsson, K. Perttu (Eds.), Willow Vegetation Filters for Municipal Wastewaters and Sludges. A Biological Purification System, Swedish University of Agricultural Sciences, Uppsala, 1994, pp. $153-155$.

[97] M.M. Lasat, Phytoextraction of metals from contaminated soil: a review of plant/soil/metal interaction and assessment of pertinent agronomic issues, J. Hazard. Subst. Res. 2 (2000) 1-25.

[98] A. Alriksson, B. Alriksson, M. El Make, Biomass uptake related depletion of soil Cd in a tree-species experiment on farmland in Sweden, in: W.W. Wenzel, D.C. Adriano, B. Alloway, H.E. Doner, C. Keller, N.W. Lepp, M. Mench, R. Naidu, G.M. Pierzynski (Eds.), Proceedings of the 5th International Conference on the Biogeochemistry of Trace Elements, Vienna: Boku, 1999, pp. 538-539.

[99] L. Yi, Y. Hong, D. Wang, Y. Zhu, Determination of free heavy metal ion concentrations in soils around cadmium rich zinc deposit, Geochem. J. 41 (2007) 235-240.

[100] A. Kabata-Pendias, H. Pendias, Trace Elements in Soils and Plants, CRC Press, Boca Raton, FL, 1992

[101] M.S. Rakesh Sharma, N.S. Raju, Correlation of heavy metal contamination with soil properties of industrial areas of Mysore Karnataka, India by cluster analysis, Int. Res. J. Environ. Sci. 2 (2013) 22-27.

[102] X. Ma, S. Zhu, S. Ai, B. Liu, R. Guo, W. Zhang, Y. Zhang, Density-dependent accumulation of heavy metals in spring wheat (Triticum aestivum) and the risk assessment from weak alkaline soils, Northwestern of China, Int. J. Agric. Sci. Technol. 4 (2016) 1-7. 